\title{
Fabrication and Characteristics of High Quality AlGaAs Film Grown on $\mathrm{Al}_{2} \mathrm{O}_{3}$ Substrate
}

\author{
Hyung-Joo Lee ${ }^{1, *}$, Young-Dae Cho ${ }^{1}$, Seong-Un Kim ${ }^{2}$, and Jae-Hoon Kim ${ }^{3}$ \\ ${ }^{1}$ CF Technology Division, AUK Corporation, Iksan, Jeonbuk 513-5, Republic of Korea. \\ ${ }^{2}$ Manufacturing Technology Team, ILJIN LED Corporation, Ansan, Gyeonggido 178-1, Republic of Korea. \\ ${ }^{3}$ Wonkwang University, Iksan, Jeonbuk 570-749, Republic of Korea.
}

\begin{abstract}
In this work, the characteristics of $\mathrm{AlGaAs}$ film grown on transparent $\mathrm{Al}_{2} \mathrm{O}_{3}$ substrate are investigated. AlGaAs films having various Al compositions were fabricated on the GaAs buffer layer of an $\mathrm{Al}_{2} \mathrm{O}_{3}$ substrate using metal organic chemical vapor deposition. It was found that the crystal quality and surface roughness of the AlGaAs film was gradually improved by increasing the $\mathrm{Al}$ composition. The relatively improved surface and crystallizations were observed at $\mathrm{AlGaAs}$ film having an $\mathrm{Al}$ composition of $80 \%$. A marked decrease in the $\mathrm{d}$-spacing between the $\mathrm{AlGaAs}$ plane and $\mathrm{Al}_{2} \mathrm{O}_{3}$ substrate was clearly observed under the same condition. From these results, the high-quality $\mathrm{AlGaAs}$ film on the $\mathrm{Al}_{2} \mathrm{O}_{3}$ substrate was attributed to an increase in the substitutional effect of $\mathrm{Al}$ for Ga caused by increasing the $\mathrm{Al}$ composition.
\end{abstract}

Keywords: - $\mathrm{AlGaAs}, \mathrm{Al}_{2} \mathrm{O}_{3}, \mathrm{GaAs}, \mathrm{MOCVD}$

\section{INTRODUCTION}

AlGaAs materials are known to be suitable for optical devices such as solar cells, laser diodes, and light emitting diodes because of their higher mobility and direct band-gap structure [1-4]. Over the past several decades, the efficiency of optical devices based on AlGaAs materials has been significantly improved using progressive growth systems and then applying more effective structures [5,6]. However, although numerous works have reported optical devices having a high efficiency, certain intrinsic limitations remain that considerably decrease their overall efficiency.

Specifically, it was shown that the efficiency of optical devices markedly decreased when using an absorbing GaAs substrate [7], though this type of substrate has been deemed necessary for fabricating optical devices based on an AlGaAs material because GaAs is typically lattice-matched with AlGaAs.

Some studies have also shown that the efficiency of optical device could be increased by inserting a distribution Bragg reflector (DBR), consisting of $\mathrm{n}$-AlAs and $\mathrm{n}-\left(\mathrm{Al}_{0.5} \mathrm{Ga}_{0.5}\right) \mathrm{As}$, between the device and absorbing substrate [8]. Elsewhere, AlGaAs having a rough $150 \mu \mathrm{m}$ thickness was used as the transparent substrate in order to fabricate higher efficiency optical devices [9]. At present, improving this efficiency has been the main focus of many researchers, in attempts to replace the absorbing substrate with a transparent substrate through a post-wafer bonding process [10]. However, current methods remain inefficient because lower yields and additional process costs are incurred.

In this work, we grow $\mathrm{AlGaAs}$ films on a transparent $\mathrm{Al}_{2} \mathrm{O}_{3}$ substrate under various $\mathrm{Al}$ compositions, subsequently finding that the crystallization and surface roughness of the AlGaAs film is significantly influenced by the $\mathrm{Al}$ composition. Here, a high quality AlGaAs film is obtained at an $\mathrm{Al}$ composition of $80 \%$.

\section{EXPERIMENTAL}

The AlGaAs films developed were grown on an $n$-type $\mathrm{Al}_{2} \mathrm{O}_{3} \mathrm{C}$-plane (1111) substrate at a $0.2^{\circ}$ tilt toward $[\mathrm{M}$-Axis $] \pm 0.1^{\circ},[\mathrm{A}$-Axis $] \pm 0.15^{\circ}$ using a metal organic chemical vapor deposition (MOCVD) system. Here, trimethylgallium (TMGa) and trimethylaluminum (TMAl) were used as the group III sources and arsine $\left(\mathrm{AsH}_{3}\right)$ was used as the group V source; hydrogen $\left(\mathrm{H}_{2}\right)$ was used as the carrier gas for all sources.

The GaAs used as the buffer layer was grown on an $\mathrm{Al}_{2} \mathrm{O}_{3}$ substrate for 5 min at $650{ }^{\circ} \mathrm{C}$ using an MOCVD system, in which the group V/III ratio used to grow the GaAs buffer layer was 52. Then, AlGaAs films having various $\mathrm{Al}$ compositions were grown on the $\mathrm{GaAs}$ buffer layer having an $\mathrm{Al}_{2} \mathrm{O}_{3}$ substrate for $10 \mathrm{~min}$ at a growth temperature of $650{ }^{\circ} \mathrm{C}$; the group V/III growth ratio of the AlGaAs films was 30. In this work, both the $\mathrm{Ga}$ and $\mathrm{Al}$ were precisely introduced into the reactor chamber using a mass flow controller (MFC) in MOCVD. During experiments, $\mathrm{Ga}$ and $\mathrm{Al}$ bubblers were used to maintain a constant temperature of $0{ }^{\circ} \mathrm{C}$ and $17{ }^{\circ} \mathrm{C}$, respectively, under a pressure of 1,000 mbar.

The crystallization and interactive growth direction for the $\mathrm{AlGaAs}$ films grown on the $\mathrm{Al}_{2} \mathrm{O}_{3}$ substrate were measured using the $\omega-2 \theta$ and mapping scans of x-ray diffraction (XRD). The surface morphology and cross-section images were then obtained through atomic force microscopy (AFM) and scanning electron 
microscopy (SEM), respectively. In addition, x-ray photoelectron spectroscopy (XPS) was used to measure the relative percent of distribution of each atom included into the $\mathrm{AlGaAs}$ films grown on the $\mathrm{Al}_{2} \mathrm{O}_{3}$ substrate.

\section{RESULTS AND DISCUSSION}

Fig . 1(a) and (b) show cross-sectional scanning electron microscopy (SEM) images of GaAs and $\mathrm{AlGaAs}$ films grown on the $\mathrm{Al}_{2} \mathrm{O}_{3}$ substrate. In the figures, the $\sim 0.2 \mu \mathrm{m}$ thick GaAs film and the $0.8 \mu \mathrm{m}$ thick $\mathrm{AlGaAs}$ film were grown flatly on the $\mathrm{Al}_{2} \mathrm{O}_{3}$ substrate. Overall, the practical thickness of AlGaAs film is $\sim 0.6$ $\mu \mathrm{m}$ because the AlGaAs film was grown directly on the GaAs film used as buffer layer. Fig. 1(c) shows the $\omega$ $2 \theta$ scan XRD results obtained from these samples. The $\mathrm{Al}_{2} \mathrm{O}_{3}\left(\begin{array}{lll}0 & 0 & 12\end{array}\right)$ peak was observed at the same point $\left(45.17^{\circ}\right)$ in all samples, whereas the GaAs $\left(\begin{array}{lll}0 & 0 & 6\end{array}\right)$ peaks were observed at $44.79^{\circ}$, near the $\mathrm{Al}_{2} \mathrm{O}_{3}\left(\begin{array}{lll}0 & 0 & 12\end{array}\right)$ peak. Note that the AlGaAs $\left(\begin{array}{ll}0 & 0\end{array}\right)$ peak at $44.77^{\circ}$ shows a higher intensity and slightly left-shifted position compared to the GaAs $\left(\begin{array}{lll}0 & 0 & 6\end{array}\right)$ peak. From these results, it was confirmed that a flat AlGaAs film could be effectively grown on an $\mathrm{Al}_{2} \mathrm{O}_{3}$ substrate by using a GaAs buffer layer.

To obtain further improved $\mathrm{AlGaAs}$ films, $\mathrm{AlGaAs}$ films having various $\mathrm{Al}$ compositions were grown on the $\mathrm{Al}_{2} \mathrm{O}_{3}$ substrate. The component ratio of $\mathrm{Al}$ to $\mathrm{Ga}$ in the AlGaAs material displayed a trade-off relationship. Fig. 2 presents the XRD results for AlGaAs films having Al compositions ranging from $20 \%$ to $80 \%$. At an $\mathrm{Al}$ composition of $40 \%$, the AlGaAs peak was left-shifted slightly. The peaks from $20 \%$ and $40 \%$ were at $44.77^{\circ}$ and $44.74^{\circ}$, respectively. Above $60 \%$, significant left-shifted movements were observed from the AlGaAs film peaks of. At $80 \%$, a peak of $44.53^{\circ}$ was observed, which is markedly left-shifted compared to the GaAs film.

Fig. 3 presents the results of an XPS analysis for AlGaAs films having various Al compositions. XPS analyses have often been used to measure the relative content of atomics in a material [11]. For this analysis, etching was performed on the top surface of the sample. In the figure, it is seen that basic atoms such as $\mathrm{Ga}, \mathrm{As}$, $\mathrm{Al}$, and $\mathrm{O}$ were obtained from the $\mathrm{AlGaAs}$ films based on the $\mathrm{Al}_{2} \mathrm{O}_{3}$ substrate ; the curve inversion presents the boundary between the $\mathrm{AlGaAs}$ film and the $\mathrm{Al}_{2} \mathrm{O}_{3}$ substrate. In addition, regions having the highest percent of $\mathrm{Ga}$ atom are observed in GaAs films used as the buffer layer. From the figure, the atomic percent of Ga was seen to be strongly influenced by the insertion of $\mathrm{Al}$ atoms because they have a trade-off relationship. However, it also seems that both As and $\mathrm{O}$ were slightly influenced by the $\mathrm{Al}$ atoms. At an $\mathrm{Al}$ composition of $60 \%$, the atomic percent of Ga decreased by $3 \%$ for $\mathrm{Al}$ increases of $20 \%$; there was a significant decrease in Ga atoms of $12 \%$ observed at $80 \%$. Overall, a marked increase in $\mathrm{Al}$ atoms was observed, one that ultimately exceeded the As atomic percent.

Fig. 4 shows AFM images for AlGaAs films grown on the $\mathrm{Al}_{2} \mathrm{O}_{3}$ substrate, in which the surface morphology is seen to improve with an increase in $\mathrm{Al}$ the composition. At $80 \%$, the surface morphology was very smooth. In the inset, the rms results clearly show that there was a marked improvement in surface morphology at an $\mathrm{Al}$ composition of $80 \%$.

The XRD map images obtained from AlGaAs films fabricated under various $\mathrm{Al}$ compositions are shown in Fig. 5. As the d-spacing presents the difference between the theta-2 theta line of substrate and matched-line from substrate to grown material, we measured the interactive growth crystallization between the $\mathrm{Al}_{2} \mathrm{O}_{3}$ substrate and AlGaAs film. Specifically, the d-spacing could be related to the condition of the latticematch between two materials having different lattice constants. In the figure, the strain and relaxation of the lattice-match increased and decreased, respectively, with a decrease in d-spacing. Previous reports have shown that the poor crystal quality and defects could be attributed to an increase in the relaxation between materials [12]. Therefore, it was assumed here that an AlGaAs film having a higher crystal quality and lower defects could be obtained by using a higher $\mathrm{Al}$ composition, especially as the $\mathrm{d}$-spacing could be effectively decreased by increasing the $\mathrm{Al}$ composition. In particular, a marked decrease in the d-spacing was clearly observed at $80 \%$. These results thus confirmed that the crystallization of the $\mathrm{AlGaAs}$ film grown directly on an $\mathrm{Al}_{2} \mathrm{O}_{3}$ substrate strongly depends on an effective substitution of $\mathrm{Al}$ to $\mathrm{Ga}$.

\section{CONCLUSION}

In this work, we directly grew $\mathrm{AlGaAs}$ films on a transparent $\mathrm{Al}_{2} \mathrm{O}_{3}$ substrate. To improve the crystal quality, $\mathrm{AlGaAs}$ films having various $\mathrm{Al}$ compositions were then grown on the $\mathrm{Al}_{2} \mathrm{O}_{3}$ substrate using MOCVD. It was found that the surface roughness of $\mathrm{AlGaAs}$ films were gradually improved by increasing the $\mathrm{Al}$ composition; the d-spacing between the AlGaAs $\left(\begin{array}{lll}0 & 0 & 6\end{array}\right)$ plane and $\mathrm{Al}_{2} \mathrm{O}_{3}\left(\begin{array}{lll}0 & 0 & 12\end{array}\right)$ substrate displayed the same trend as the surface roughness. From the experimental results, it was thus posited that the crystallization and surfaces of $\mathrm{AlGaAs}$ films grown on $\mathrm{Al}_{2} \mathrm{O}_{3}$ substrate depend strongly on the $\mathrm{Al}$ composition. At $80 \%, \mathrm{AlGaAs}$ films having a relatively higher crystal quality and improved surface were obtained compared to previous reports. From these results, the high-quality $\mathrm{AlGaAs}$ films grown on $\mathrm{Al}_{2} \mathrm{O}_{3}$ substrates was subsequently attributed to an increase in the substitutional effect of $\mathrm{Al}$ for $\mathrm{Ga}$ caused by the increase in $\mathrm{Al}$ composition. 


\section{ACKNOWLEDGEMENTS}

This work was supported by a Korea Research Foundation Grant from the ATC project (No. 10035863) by the Ministry of Knowledge and Economy, Korea.

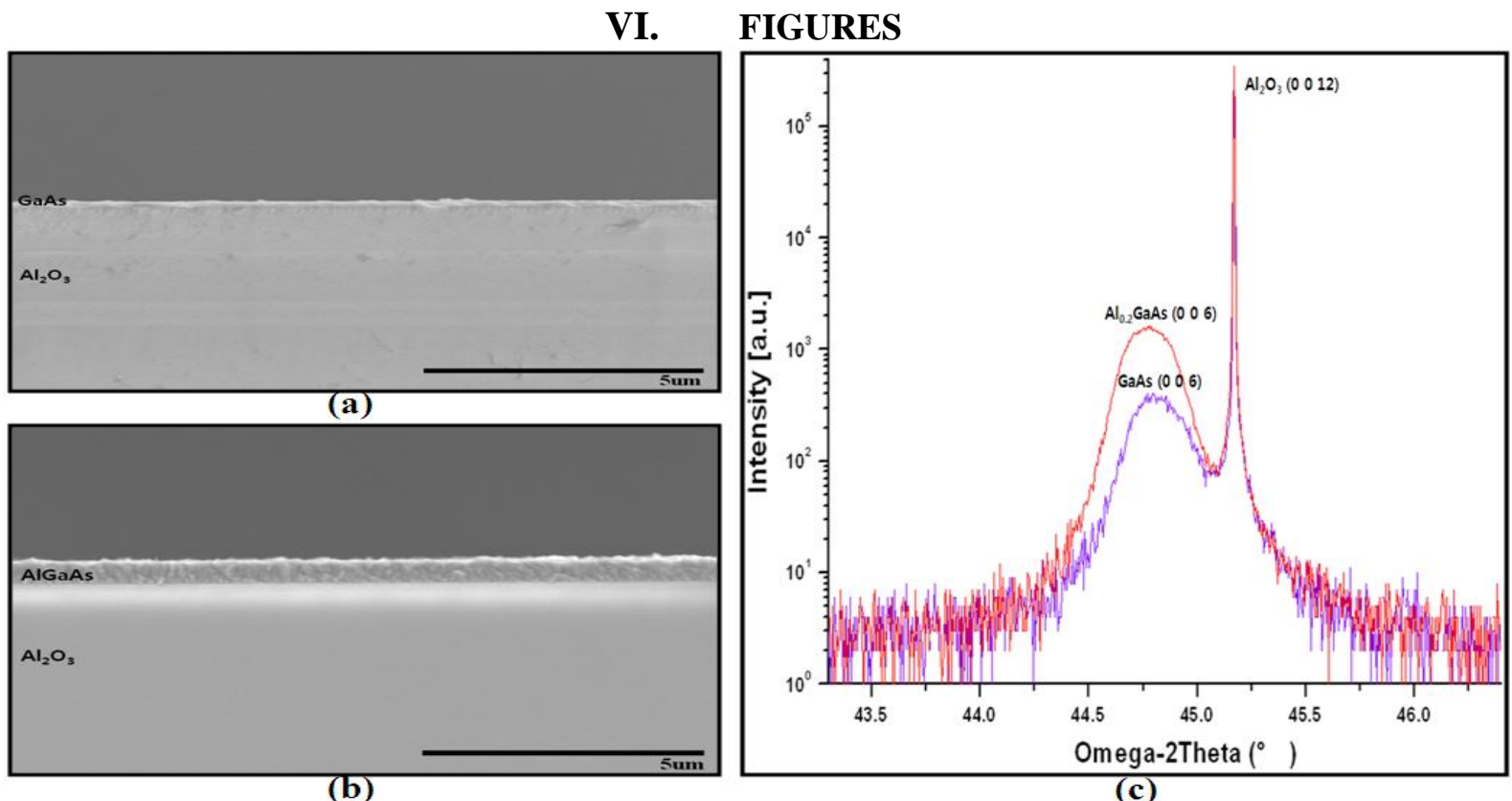

Fig. 1. (a)-(b) SEM and (c) XRD images for $\mathrm{AlGaAs}$ and $\mathrm{GaAs}$ films grown on $\mathrm{Al}_{2} \mathrm{O}_{3}$ substrates.

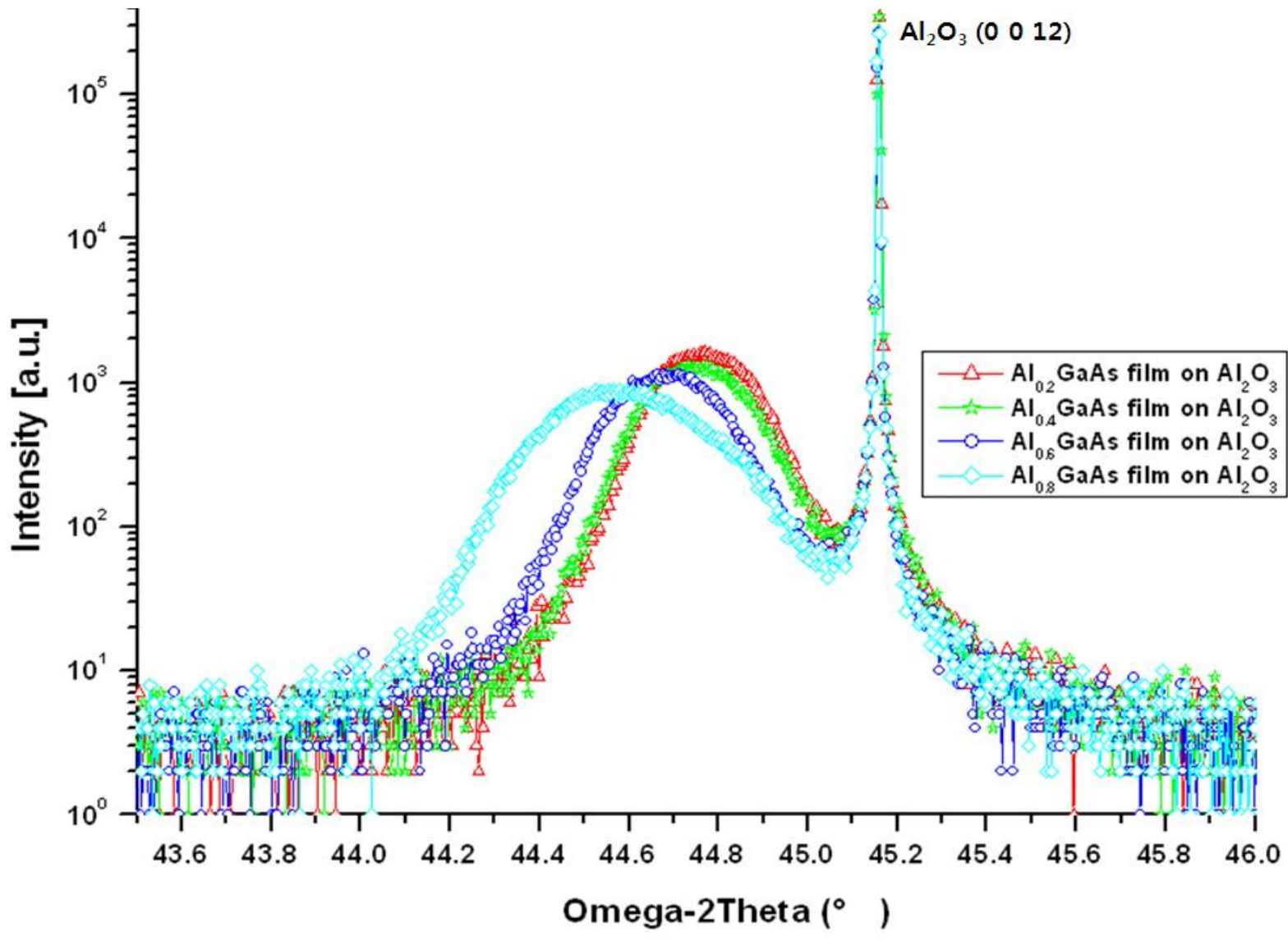

Fig. 2. XRD results for $\mathrm{AlGaAs}$ films having various $\mathrm{Al}$ compositions on an $\mathrm{Al}_{2} \mathrm{O}_{3}$ substrate. 


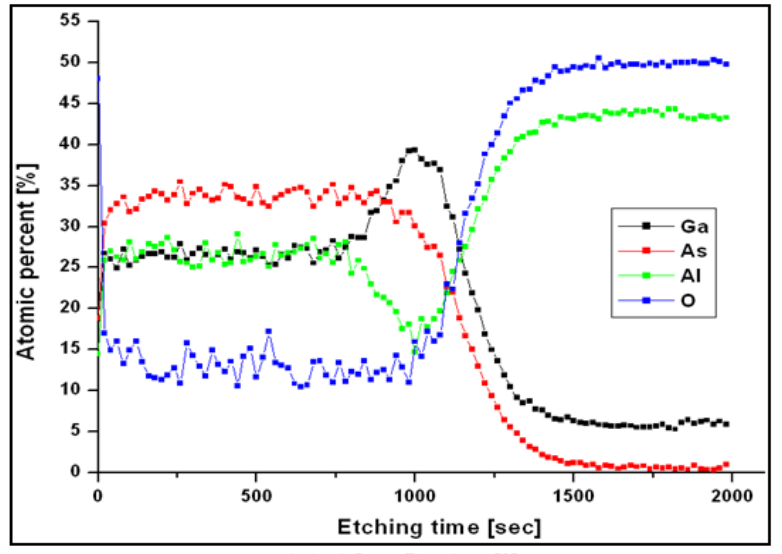

(a) $\mathrm{Al}_{0.2} \mathrm{GaAs}_{\mathrm{Ailm}}$

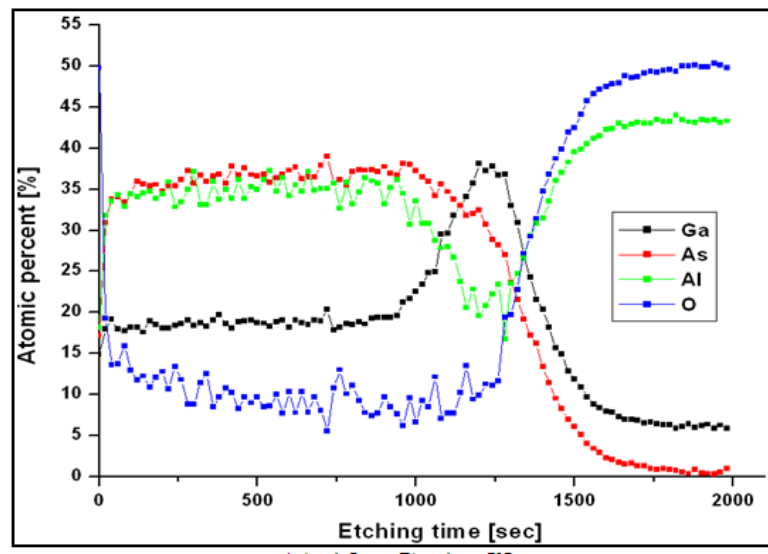

(c) $\mathrm{Al}_{0.6} \mathrm{GaAs}$ film

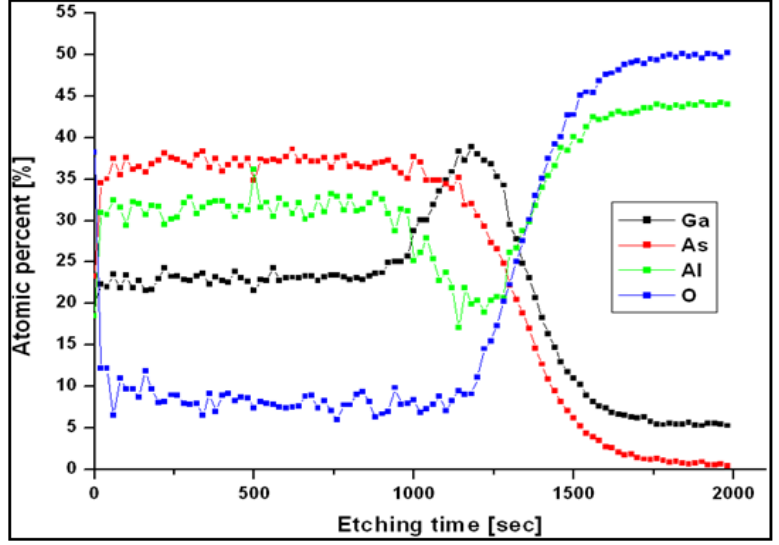

(b) $\mathrm{Al}_{0.4} \mathrm{GaAs}$ film

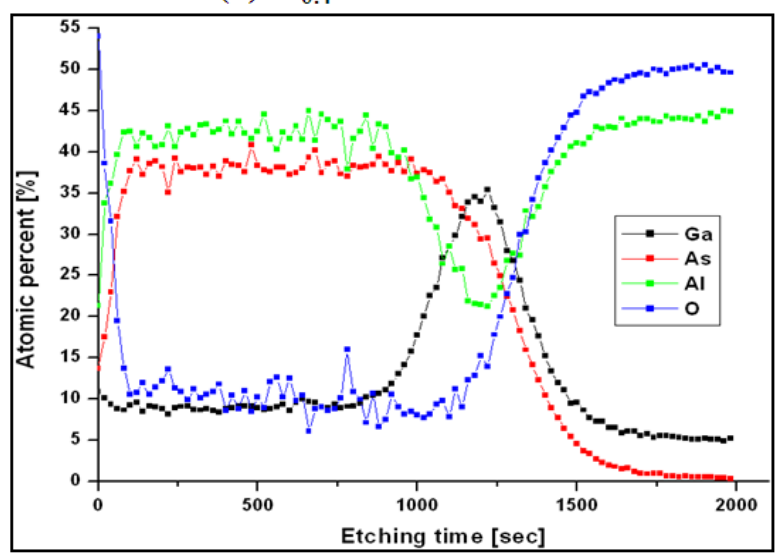

(d) $\mathrm{Al}_{0.8} \mathrm{GaAs}$ film

Fig. 3. XPS analyses of $\mathrm{AlGaAs}$ films having various $\mathrm{Al}$ compositions on an $\mathrm{Al}_{2} \mathrm{O}_{3}$ substrate.

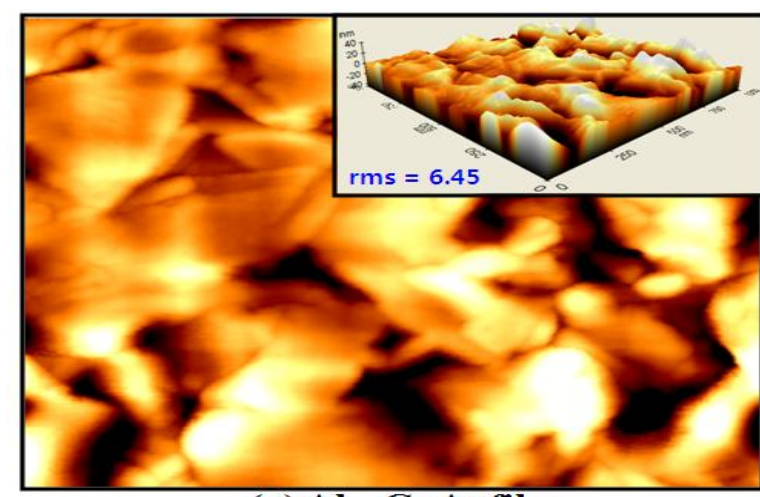

(a) $\mathrm{Al}_{0.2}$ GaAs film

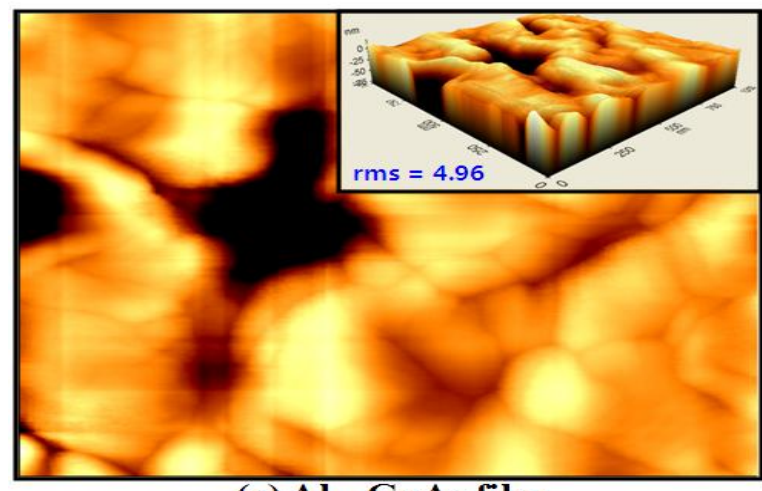

(c) $\mathrm{Al}_{0.6} \mathbf{G a A s}$ film

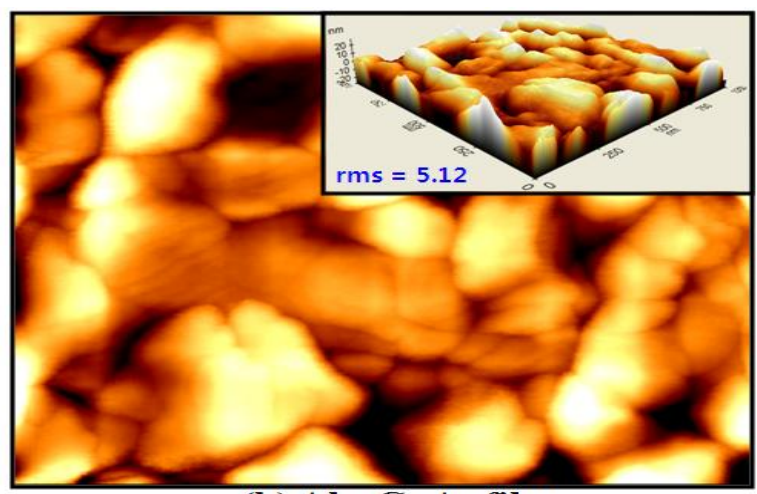

(b) $\mathrm{Al}_{0.4} \mathrm{GaAs}$ film

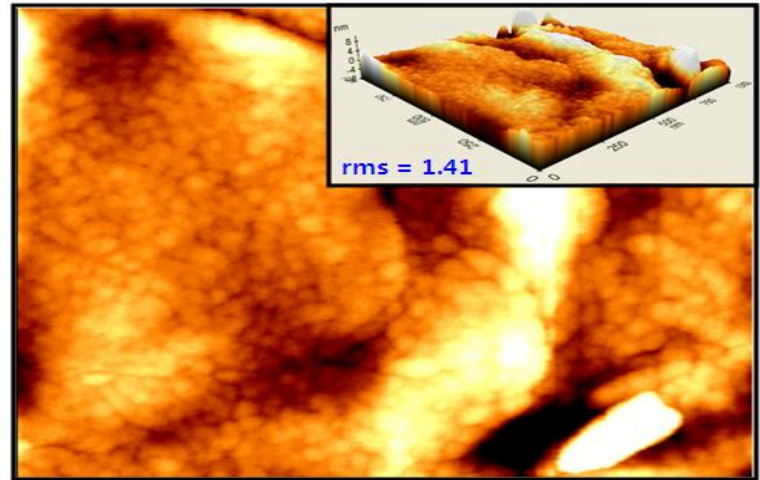

(d) $\mathrm{Al}_{0.8} \mathrm{GaAs}$ film

Fig. 4. $\mathrm{AFM}$ images for $\mathrm{AlGaAs}$ films having various $\mathrm{Al}$ compositions on an $\mathrm{Al}_{2} \mathrm{O}_{3}$ substrate. 


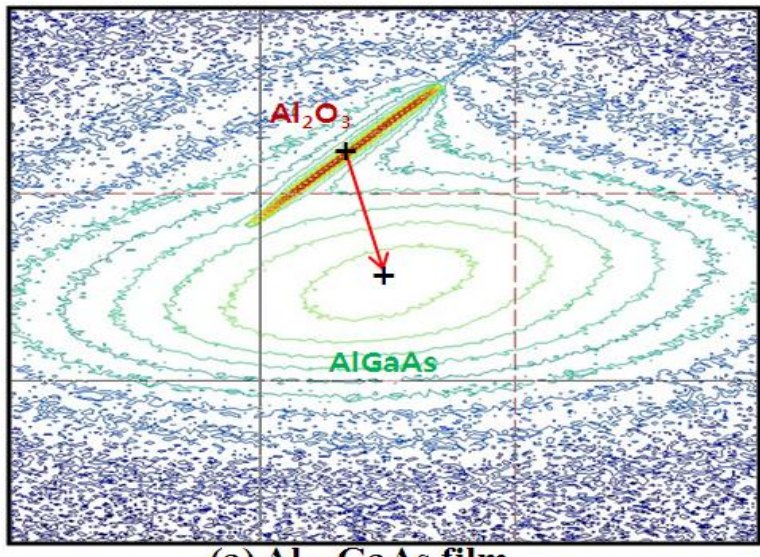

(a) $\mathrm{Al}_{0.2} \mathrm{GaAs}$ film

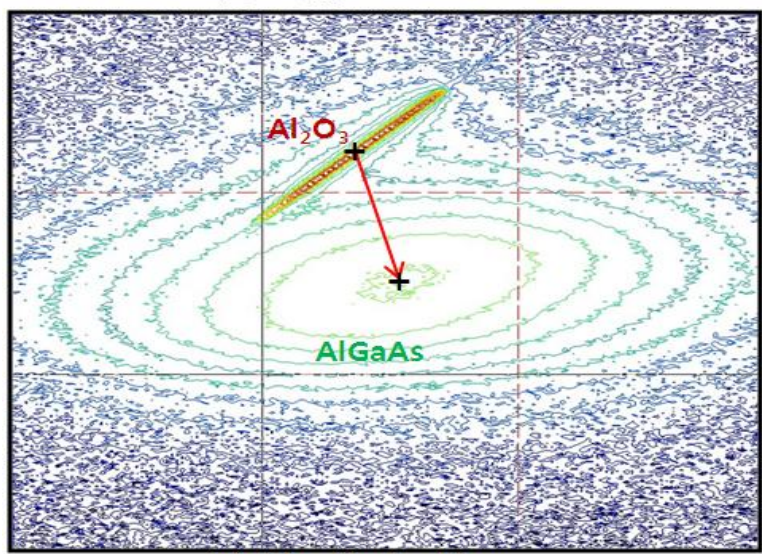

(c) $\mathrm{Al}_{0.6} \mathrm{GaAs}$ film

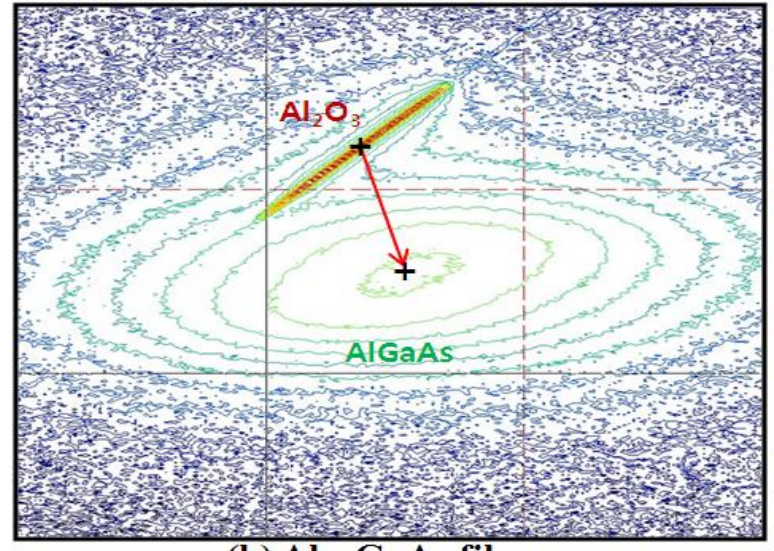

(b) $\mathrm{Al}_{0.4} \mathrm{GaAs}$ film

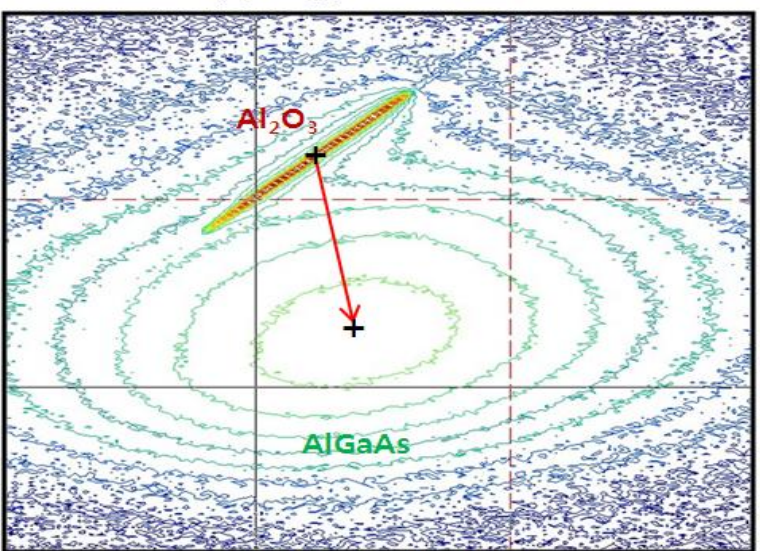

(d) $\mathrm{Al}_{0.8} \mathrm{GaAs}$ film

Fig. 5. XRD map images showing d-spacing between $\mathrm{Al}_{2} \mathrm{O}_{3}$ and $\mathrm{AlGaAs}$ films having various $\mathrm{Al}$ compositions.

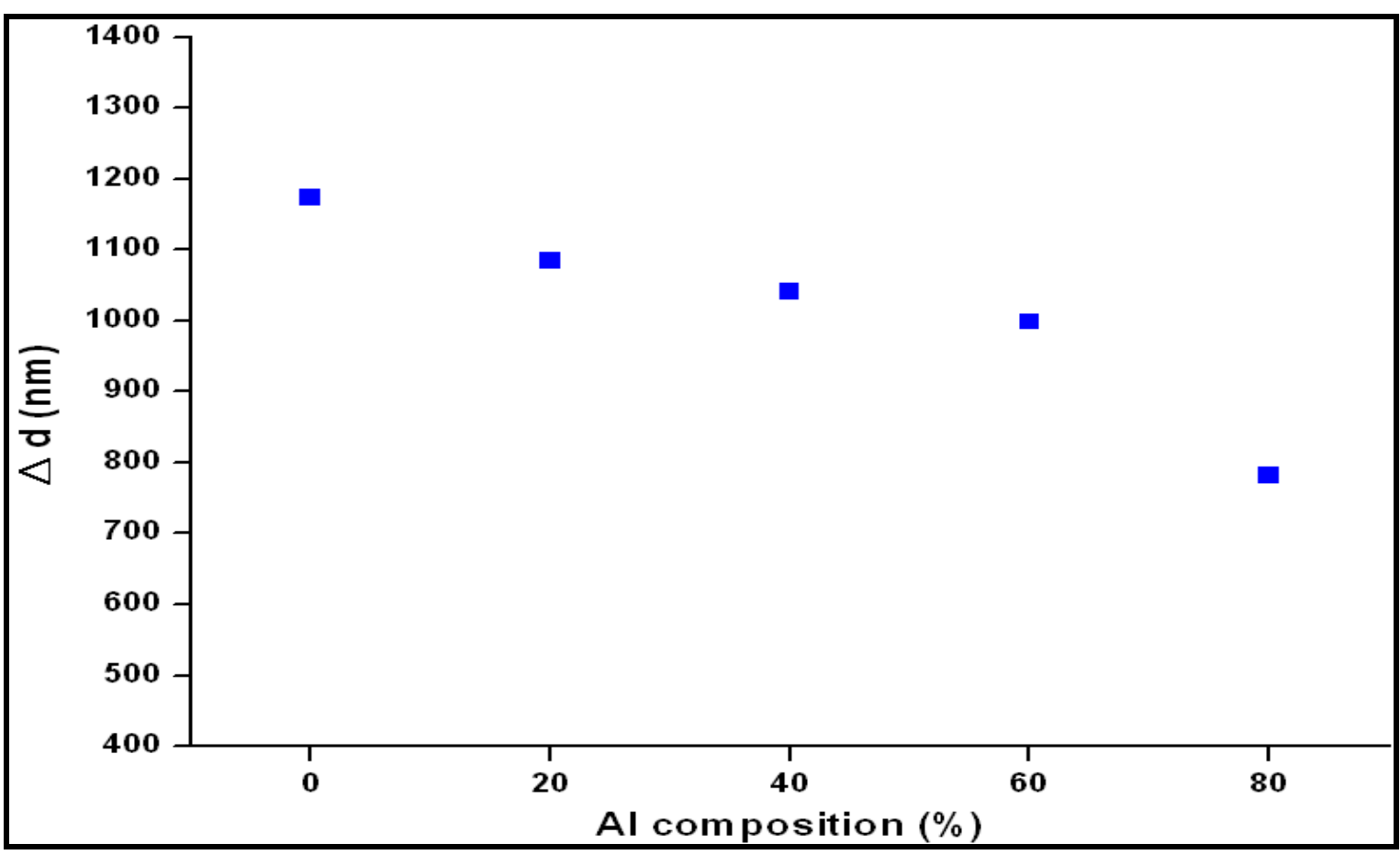

Fig. 6. Results of d-spacing obtained between $\mathrm{Al}_{2} \mathrm{O}_{3}$ and $\mathrm{AlGaAs}$ films having various $\mathrm{Al}$ compositions. 


\section{REFERENCES}

[1] X. Q. Liu, C. M. Fetzer, E. Rechder, H. Cotal, S. Mesropian, D. Law, and R. R. King, Organometallic vapor phase epitaxy growth of upright metamorphic multijunction solar cells, Journal of Crystal Growth 352 (2012) 186-189.

[2] F. A. Kish, S. J. Caracci, N. Holonyak, Jr., J. M. Dallesasse, G. E. Hofler, R. D. Burnham, and S. C. Smith, Low-threshold disorder-defined native-oxide delineated buried-heterostructure $\mathrm{Al}_{\mathrm{x}} \mathrm{Ga}_{1-\mathrm{x}} \mathrm{As}$-GaAs quantum well lasers, Applied Physics Letters 58 (1991) 1765-1767.

[3] T. Kato, H. Susawa, M. Hirotani, T. Saka, Y. Ohashi, E. Shichi, and S. Shibata, GaAs/GaAsAs surface emitting IR LED with Bragg reflector grown by MOCVD, Journal of Crystal Growth 107 (1991) 832835.

[4] D. A. Neamen, Semiconductor Physics and Devices (Avenue of the Americas, NY, 2003)

[5] A. G. Thomason, MOCVD technology for semiconductors, Material Letters 30 (1997) 255-263.

[6] C. Y. Liu, S. Yuan, J. R. Dong, and S. J. Chua, Temperature dependence of photoluminescence intensity from AlGaInP/GaInP multi-quantum well laser structures, Journal of Crystal Growth 268 (2004) 426-431.

[7] E.F. Schubert, Light-Emitting Diodes ( Cambridge University Press, Edingburgh Building, UK, 2006)

[8] H. J. Lee, Y. J. Kim, S. U. Kim, J. U. Jo, C. H. Lee, J. H. Kim, and S. C. Ahn, Efficiency Improvent of $630 \mathrm{~nm}$ AlGaInP Light-Emitting Diodes based on AlGaAs Bottom Window, Japaness Journal of Applied Physics 52 (2013) 1021011-1021014.

[9] H. Kitabayashi, Y. Kawabat, H. Matsubara, K. I. Miyahara, and S. Tanaka, Development of High Power Infrared LED, SEI Technical review 70 (2010) 71-74.

[10] R. H. Horng, S. H. Hwang, D. S. Wuu, and C. Y. Chiu, AlGaInP/mirror/Si light-emitting diodes with vertical electrodes by wafer bonding, Applied Physics Letters 82 (2003) 4011-4013.

[11] F. Lefevre, D. Lorans, C. D. Chouvy, A. Etcheberry, D.Ballutaud, and R. Triboulet, Oxidation of $\mathrm{Hg}_{0.8} \mathrm{Cd}_{0.2} \mathrm{Te}$ in basic media: an XPS and spectroscopic ellipsometry study, Journal of Crystal Growth 184 (1998) 1237-1241.

[12] T. Roesener, V. Klinger, C. Weuffen, D. Lackner, and F. Dimroth, Determination of heteroepitaxial layer relaxation at growth temperature from room temperature X-ray reciprocal space maps, Journal of Crystal Growth 368 (2013) 21-28. 